American Journal of Economics and Business Administration 3 (4): 604-609, 2011

ISSN 1945-5488

(C) 2011 Science Publications

\title{
Assessment of Correspondent Banks Case Study
}

\author{
${ }^{1}$ Abeer F.A. Al Abbadi, ${ }^{1}$ Abdel Nasser T. Zyoud and ${ }^{2}$ Sinan S. Abbadi \\ ${ }^{1}$ Department of Economic Finance and Banking, \\ Faculty of Business and Finance, \\ The World Islamic Sciences and Education University, Jordan \\ ${ }^{2}$ Department of Accounting and Finance, \\ Faculty of Business and Finance, Al Balqa' Applied University
}

\begin{abstract}
Problem statement: This study aims at evaluating corresponding banks in Jordan. Characterizing the goals, instruments and profitability under unfavorable conditions of financial setbacks and unfair competition among banks. Focuses on the feasibility and profitability of Philadelphia Investment Bank in its international trade via its Correspondent banks. Approach: Problems and setbacks shall be screened out; reasoned and appropriate optimal recommendations are to be presented. Results: The study followed the analytical approach and depended on "History Documents" and "In depth Interview" techniques and puts a major emphasis on the fact that correspondent banking has become an essential cornerstone of international business amid the new era of world trade, globalization, external competition and cartels from the major opponents to Jordanian Banks, the main conclusion is realized the importance of correspondent banks in the international trade, so Philadelphia bank benefited from correspondent banks for the cheap cost of market entry and services were tailored to the scale of required locale. But there was no big investment in staff facilities. And there are setbacks in dealing with correspondent banks, such as fund delay in reaching destinations on time. Moreover, Jordanian banks have suffered in general from these correspondent banks because they deal with these correspondent banks individually. Conclusion/Recommendations: The recommendation of the study is, it is the time to consider solidification and forming one financial block, or a sort of cartel and face these correspondent banks in one unit. They are also called for developing collective strategies. Small banks should merge and form huge capital blocks. Another strategy is that Jordanian banks should minimize the reliance on foreign banks and should develop their own, by establishing international branches abroad to help financing their international activities.
\end{abstract}

Key words: Correspondent banks, assessment strategy, global banking, banking system, international banking, Bank service, Jordanian banks, setbacks

\section{INTRODUCTION}

Jordan is located in the middle heart of the Middle East countries. Jordan is a country with no natural resources compared with its neighbors of Gulf States and Iraq it shares with them the desert.

However, Jordan is a country with high level of political stability and with high caliber of its human recourses; Jordanians are talented, knowledgeable and innovative (Brynen, 1992). Jordan has rationally succeeded in establishing well organized financial markets; it has exported this knowledge to many of its neighboring Gulf States like U.A.E., Oman and Qatar.

Jordan has a regulated Banking System, a system with high reputation among peers in the neighboring countries and internationally .Many international banks in the U.S.A. AND EUROP serve as correspondent banks to many Jordanian banks Ministry of Planning, 2009.

This study is intended to enhance our understanding the relation between Jordan banks and their correspondents; a pilot study has been set up to study and assess the relation between PHILADELPHIA INVESTMENT BANK with its correspondent banks.

Research problem: The Philadelphia Investment Bank Lack to realize the importance of a clear policy to deal with correspondent banks and lose of revenue is supposed to verify the services of world trade. So the study focuses on the feasibility and profitability of

Corresponding Author: Abeer F.A. Al Abbadi, Department of Economic Finance and Banking, Faculty of Business and Finance, The World Islamic Sciences and Education University, Jordan 
Philadelphia Investment Bank in its international trade via its Correspondent bank. Problems and setbacks shall be screened out; reasoned and appropriate optimal recommendations are to be presented.

Prime objective of this study: Since 1990's, the world economy and financial markets have been undergoing a process of increasing globalization and structural changes.

This continuing trend has created a range of complex financial and strategic concerns for practitioners in MNC'S, Capital Markets, Finance and international banking.

In this study, we aim to developing a sound understanding of strategies and methodological issues in international and correspondent banking and their effect on Jordan's banking system.

Globalization and international banking (preview): Globalization is the spreading of financial services and financial instructions worldwide.

Since 1980, technological advances such as global telecommunication and computer networks have reduced geographical and even cultural distances. As a result, companies can now buy supplies, produce and sell goods and services in countries far from their homes. Products and services conceived in one country are now being manufactured and then sold in many others (Mehta and Fung, 2004).

Financial institutions are establishing interstate operations and expanding their marketing programs to cover the whole globe. As a result, geographical barriers are falling to international competition and strong pressures to consolidate smaller financial-services institutions into larger ones (Rose and Marquis, 2007).

The growth of world economy since the end of World War II have been paralleled by expansion of global banking activities. Banks followed their customers overseas. This is viewed by the fact that international bank loans extended by commercial banks located in major financial centers around the world have increased over the past 25 years (Shapero, 2009). Many changes in international activities are taking place more rapidly than at any other time in history. Companies of many nationalities are expanding their international investments, some are exporting, others are establishing foreign facilities and some of the largest enterprises are becoming global companies in the integrated technology with world brand products and services. In nearly all these instances, these companies and institutions are searching opportunities among promising transition economies where international markets promise accelerated growth of free trade. These trends mean a greater need for international financial institutions who must work in more complex, multinational systems (Saunders and Cornett, 2007).

The international trade activities have grown in importance over time. This trend is attributable to the increased globalization of world economies and the availability of trade finance from the international banking community. Although banks finance domestic trade, their role in financing international trade is more critical due to many complications involved: (a) Exporters might question the importer's ability to make payment. (b) Even if importer is creditworthy, government might impose exchange controls that may prevent payment to exporter. (c) The importer might not trust the exporter to ship goods ordered. (d) Even if the exporter does ship the goods, trade barriers or time lags in international transportation might delay arrival time (Madura, 2009).

International trade and financial system would not be complete without the role of international banking institutions, trough these firms, the majority of commercial and financial transactions flow and cross all international borders .International banks offer a wide range of international financial services to customers including buying and selling foreign exchange ,issuing L/Cs, accept deposits , and grant loans . However, in its long standing history, the international banking system has been subjected to a series of shocks to its stability and growth.

Recurrent crises that have sometimes shaken the global banking system to its roots (The domino effect) in international banking, the Japanese problem in 1990 is an example.

Correspondent Banks: A Correspondent bank is a bank that regularly performs services for $\mathrm{j}$ another financial institution which is usually located in another country or marketing area .Typical services include handling out of area checks, trusts and technical services. Overall, a correspondent bank is one that backs up the limitations of a smaller bank, a foreign bank, a merchant bank, or any other financial institutions that would need to "farm out" certain procedures, or services not available at the respondent bank. Many Community banks clear out-of-town checks through reserve accounts at larger banks (Rose and Hudgins, 2009). Correspondent banking allows foreign banks to conduct business in the home country and provide services for their customers in areas where the bank does not maintain a physical presence. In a nutshell, foreign banks open correspondent accounts with local banks to avoid the expenses of operating a local bank. 
Correspondent banking enjoys many advantages and as well it encounters some concerns, or may be some disadvantages.

Major advantages: The correspondent route, i.e., the cost of market entry is minimal and can be adjusted to the scale of service required in a given locale, the bank also enjoys the benefits derived from having multiple sources of business given and received, as well as referrals of local banking opportunities. No investment in staff or facilities is required. Moreover, correspondents' local knowledge and contacts may be extensive and highly useful in rendering services to the bank's clients.

Major disadvantages: Correspondent banking faces the country risk represented by some restrictive practices, the exchange rates of the foreign country, foreign government blockage of fund transfers and some correspondent banks may assign low priority to the needs of the respondent bank. Due to legal restrictions on traditional banking polices, certain types of credits may be difficult to arrange. Some correspondent banks are reluctant to provide credits on a more regular and extensive bases (Shapero, 2009).

A correspondent banking team is usually committed to providing quality products and services. A team of specialists works one-on-one to understand the unique requirements and the complex issues that impact business.

International and other banks require international banking partners who would provide the global reach and trade services that cannot be addressed alone. Clients usually benefit from the correspondent banks experience in international trade, enjoying the access to the extensive global network and advanced trade technology to expedite their cross border transactions.

Capabilities of correspondent banks shall include the basic services of bank to bank reimbursements that would consolidate all the funding requirements at the correspondent bank so as to avoid maintaining idle balance pools with multiple banks in anticipation of reimbursement claims and provide consolidated predebit advices, real time balance and transaction reporting and overnight investment services for excess balances. Export bill collections combine courier delivery of open receivable letters, payment tracing, tracking reporting and received funds, concentration to quickly deposit the funds due from export receivables into the client's account while keeping him informed of paid items. The strategic alliance program which enables the respondent bank to utilize the correspondent trade operations as its own-substantially reducing the international trade processing costs, while serving the respondent's client base more efficiently with a broader range of products. Correspondent bank is maintained as the primary service provider and the respondent will manage the client's relationship under its own "private lable". Correspondent bank has to have an extensive banking network with good correspondent relationships worldwide. It should be a private of global trade services with trade specialty and trade operations processing sites creating international coverage. It has to be associated in all countries involved in operations, business development and support trade banking activities (Mehta and Fung, 2004).

\section{Pilot study:}

\section{Philadelphia investment bank:}

Bank profile: Philadelphia Investment Bank is one of Jordan's investment banks.

It concentrates business in international trade in addition to domestic traditional banking operations.

Bank was established in 1982 as financial company named "Jordan Finance House", in 1992 it was merged with a securities trading company. "Jordan Securities Co...

In the period 1993-2001, many of Jordan's banks were engaged in the I bilateral trade between Jordan and Iraq that started aftermath the second Gulf War. Also UN. Security Council has implemented full scale sanctions on Iraq, but allowed the passage of certain food stuffs to Iraq in a program named "Oil for Food". All shipments were I financed by the United Nation who also receives the revenues of all oil sales; a special committee was formed to administer this program.

This period was an excellent period to test the efficiency and credibility of all correspondent banks who were the financiers of most Jordanian banks.

Philadelphia Investment Bank was well known to many Iraqi business people and to some Iraqi officials .The average Iraqi official deposits were \$ 150-170 million, while the Iraqi private sector's deposits were \$ $70-90$ million. About $80 \%$ of the bank's international trade for the period 1994-2001 was for Iraq.

Research techniques: The researcher used "History Documents" and "In depth Interview" techniques.

History Documents helped in knowing the organization structure of the Correspondent Banking Division, or The Division of Foreign Relations Management.

This division has the basic objective in having clear correspondent relations with foreign banks to enhance the ability of the bank to carry out its international financial transactions for the interest of its clients (Rose and Hudgins, 2009). 
The Foreign Affairs Department regulates and manages the activities pertaining all transactions that take place between the Head Office in Amman-Jordan and each of these correspondent banks. That department is subdivided into sections in which each is specialized in monitoring certain operations. As per agreements with correspondent banks, this division manages the agreements between the head office and each of these correspondent banks.

The Foreign Accounting Department is one of the most important departments in this division.

This department acts upon the agreements and protocols of cooperation with its counterpart's. All accounting transactions are set upon the agreements signed Draft of a typical agreement. Also foreign currencies are maintained in both volume and type using the same sense. All accounting transactions in the corresponding bank books shall match those of the corresponding bank books. Discrepancies are checked thoroughly and promptly.

Follow up and reconciliation have to be conducted continuously by both concerned parties.

Management of foreign operations is deeply important; the Department of foreign affairs controls its operations with the corresponding banks.

Operations department carries out the entire bank's operations of correspondent banks; it is considered as the main profit generator of the Foreign Organization Chart.

\section{Philadelphia Correspondent Banks are:}

Country Name of Bank

England/London Jordan International Midland

USA Bank of New York

France Societe Generale

Swizerland Credit Suisse

Italy Credito Italiano

Germany Commerz Bank

Sudi Arabia Riyadh Bank

Kuwait National Bank Of Kuwait '

Japan Ubaf

In-depth interviews with high ranking officials have been conducted, data has been collected and verified.

About 30-40\% of Philadelphia Investment Bank revenues are lost due to correspondent banks' conservative policy towards the bank, i.e., \$10-15 million of profits are lost annually.

- Annual revenues amount to \$20-25 million
- Expenses of international trade including correspondent banking amounts to $\$ 15-18$ million

- Many foreign investment opportunities are lost annually due to the declination of correspondent banks to extend the margin of bilateral trade between each of these banks and Philadelphia Investment Bank

- High commissions are levied on the Bank's L/Cs and Acceptances of contracts forwarded to Iraq in the 'Oil for Food' program

- Correspondent banks require full coverage of collaterals for all contracts to Iraq, claiming that Iraq is a risky area, which requires big amounts of deposits to be placed in these banks

- Insurance companies linked to correspondent banks require high charges and ask for high insurance coverage, which adds to the burden and diminishes revenues

- All Jordanian Banks in general were not given the right and appropriate attention by their correspondent banks, as the individual volume of trade for each of these banks is not highly appealing to the correspondent banks.

- Frequent delays in performing the banks' transactions

- A general attitude of most European and American correspondent banks suspect that most of the Middle East banks are related to international terrorism and thus investigates all transactions thoroughly which causes a delay in all transfers and checks clearing

\section{CONCLUSION}

In the light of research outcomes, one can realize the importance of correspondent banks in the international trade. International trade is becoming the backbone of world economy. No one country on the globe can be self sufficient, in this new era of world trade, it is of deem necessity to work in a bank network, free trade among countries of the world has opened the door wide for many international banks to branch worldwide, most of the banks in the developed countries have extended their bank services beyond their national boundaries, they have started to expand in their services across their borders.

Most of Jordanian banks are confined to work in Jordan with a few have branched outside Jordan, such as Arab Bank, National Bank, Bank of Jordan. Jordan International Bank has been established to operate in London-England to serve other Jordanian Banks in their international activities. This bank has limited capabilities and volume of international trade. 


\section{Am. J. of Economics and Business Administration 3 (4): 604-609, 2011}

Philadelphia Investment Bank has cooperation agreements with many correspondent banks; these banks offer many services such as coverage of Philadelphia international trade, i.e., L/Cs, Acceptances and Forex trade. Philadelphia bank benefited from these banks for the cheap cost of market entry and services were tailored to the scale of required locale. There was no big investment in staff facilities. Yet the bank can enjoy many benefits derived from having multiple outlets for its multiple business types. The direct overseas contacts did not pose a threat to Philadelphia Investment Bank, in the contrary, it has benefited from having multiple sources of business in addition to the referrals of local banking opportunities moreover correspondent's local knowledge and contacts have caused extensive and useful innovations to services offered to the Banks' clients.

Philadelphia Investment Bank with international branches will remain confined with its domestic branches and with traditional banking instruments. On the other hand, there are setbacks in dealing with correspondent banks, such as fund delay in reaching destinations on time; this delay confuses beneficiaries and investors alike. The miss coding, or not coding of checks, or an officer may not forward a conditional SWIFT when he should have, or that the correspondent bank changed the wording on the SWIFT, or invert the designated bank account number and that the correspondent bank is having a dispute with one of the other banks in the chain. Moreover, correspondent banks could be a potential gateway for money laundering. Studies have been conducted on correspondent accounts that showed money laundering activities, i.e., some correspondent banks were used as vehicles for money laundering. The cumulative setbacks and time lags caused by the delay in meeting deadlines of international transactions such as L/C's, L/G's and Acceptances have affected all other banks in Jordan. Amid the risks that culminated the Middle East International Banks have considered the Middle East as a hazard zone and they have diminished their main activities in the region pretending that this Area has to be reassessed for what is known as country risk. Jordanian banks have suffered in general from these correspondent banks because they deal with these correspondent banks individually. It is the time to consider solidification and forming one financial block, or a sort of cartel and face these correspondent banks in one unit. They are also called for developing collective strategies. Small banks should merge and form huge capital blocks.

Another strategy is that Jordanian banks should minimize the reliance on foreign banks and should develop their own. However, Jordanian banks should stop the reliance on foreign correspondents by establishing international branches abroad to help financing their international activities. Decisions on hoe to approach foreign markets are influenced by many variables, such as overall financial resources, level of experience with international markets and volume of international business, possible entry strategy would be the international branching, increasing representative offices and thus forming a complete international banking cycle. Cross border activities can be accomplished by Foreign Bank Branches to be located in the major international money centers such as London, New York and others. These branches will serve as correspondent banks and will provide access to the international money market These branches will save the expenses of correspondent banks and enhance revenues, they will also integrate services.

We hope to see more integrated, powerful Banks that will provide full Range of services to Jordanian business people and any other investors Worldwide.

Summary: From time to time, local banks need international strong partners to offer some extra resources to meeting the financing needs of their respondent partners. Correspondent Banking is the provision of a current, or other liability account and related services to another institution used to meet its cash clearing, liquidity management and short term borrowing, or investments needs. The institution must define policies and procedures that require specified personnel to be responsible for insuring compliance with these principles. These principles advocate a J risk-based approach. Correspondent Banking Clients presenting greater risk should be subjected to a higher level of diligence. Each institution may give the appropriate weight to each risk as it deems necessary as wolfs berg group. The number of correspondent banks is growing; soon there will be direct operational banking channel between international banks and most of the developing countries including Jordan. The Central Bank of Jordan (CBJ) is Jordan's banking system's regulatory authority.

Jordanian Banks have a total of more than 62 correspondent banks around the globe. All Jordanian banks maintain direct correspondence with U.S based banks .Each local Jordanian bank deals with at least two to three New York BASED banks. And since there are no restrictions on the flow of foreign currencies for commercial and capital transactions, Jordanian Banks were encouraged to have correspondent banks all over the globe. It is worth to note that all Jordanian Banks suffer from correspondent banks' policies that usually 
work against their interests especially in international trade services and not giving the Jordanian banks the appropriate attention.

However, Jordanian Banks are called upon to consolidate and form a financial cartel to offset any correspondent policies to tackle them individually. Also Arab Banks in total are invited for unification and forming a strong financial conglomerate to cope with the Global Banking U Blocks.

\section{REFERENCES}

Brynen, R., 1992. Economic crisis and post-rentier democratization in the Arab world: The case of Jordan. Canadian J. Political Sci., 25: 69-98. DOI: 10.1017/S000842390000192X

Madura, J., 2009. International Financial Management. 10th Edn., Cengage Learning, Australia, ISBN: 1439038333, pp: 709 .
Mehta, D.R. and H.G. Fung, 2004. International Bank Management. 1st Edn., John Wiley and Sons, Malden, Mass., ISBN: 1405111283, pp: 395.

Rose, P.S. and M.H. Marquis, 2007. Money and Capital Markets. 10th Edn., McGraw-Hill/Irwin, New York, ISBN: 0073405167, pp: 767.

Rose, P.S. and S.C Hudgins, 2009. Bank Management and Financial Services. 8th Edn., McGrawHill/Irwin, Boston, ISBN: 0071269657, pp: 734.

Saunders, A. and M.M. Cornett, 2007. Financial Markets and Institutions: An Introduction to the Risk Management Approach. 3rd Edn., McGrawHill/Irwin, Boston, Mass., ISBN: 0073041696, pp: 696.

Shapero, A.C., 2009. Multinational Financial Management. 9th Edn., John Wiley and Sons, Hoboken, N.J., ISBN: 0470415010, pp: 762. 